\title{
DERIVATIONAL AND INFLECTIONAL PREFIXES AND SUFFIXES IN BATUSESA DIALECT OF BALINESE: A DESCRIPTIVE STUDY
}

Ariani, N.K.

English Education Department, Ganesha University of Education e-mail: arianikomang94@gmail.com

\begin{abstract}
This study was designed in the form of descriptive qualitative study with the aim at describing the prefixes and suffixes in Batusesa Dialect of Balinese which belong to derivational and inflectional morpheme. The techniques used to collect the data were observation, recording and interview technique. In this study, there were three informants chosen. The results of this study show that there are four kinds of prefixes found in Batusesa Dialect, namely $\{\mathrm{n}-\},\{\mathrm{me}-\},\{\mathrm{pe}-\}$, and $\{\mathrm{a}-\}$ and five kinds of suffixes namely $\{$-ang $\},\{-n \ni\},\{-i n\},\{-a n\}$ and $\{-\partial\}$. There are three kinds of prefixes and one kind of suffixes which belong to derivational morpheme, namely $\{\mathrm{n}-\},\{\mathrm{me}-\}$, $\{\mathrm{pe}-\}$, and $\{$-ang $\}$. Moreover there are three kinds of inflectional prefixes namely $\{\mathrm{n}-\}$, $\{m e-\}$, and $\{a-\}$ and four kinds of suffixes which belong to inflectional morpheme, namely $\{-$ no $\},\{-i n\},\{-a n\}$ and $\{-\partial\}$. There were some grammatical functions of prefixes and suffixes in Batusesa dialect of Balinese, namely affix forming verbal, affix forming nominal, affix forming numeral, affix forming adjective, and affix forming adverb, activizer and passivizer.
\end{abstract}

Keyword: prefixes, suffixes, derivational, inflectional

\section{INTRODUCTION}

Language is an important aspect in human life. It is a means of communication of a person to the others. The people need language to looking for and give people benefit information. People need language as a means of communication to express their feeling, though and desire. Language has two major purposes for us that are as an instrument of communication and as a vehicle of thought (Dummett: 2002). Language as instrument of communication means that people use language to gather all of the information that people need in life. Different language communities have certain ways of talking that set them apart from others. Those differences thought as dialects, not just accents (the way words are pronounced) but also grammar, vocabulary, syntax and common expressions. Often a group that is somewhat isolated regionally or socially from other groups will develop a characteristic dialect.

Indonesia is one of countries which is very rich in term of language. There are so many different languages that can be found from Sabang to Merauke. Every island in Indonesia and even each province in Indonesia have its own language which is use by the people in those areas. One of famous language in Indonesia is Balinesse language. Like other languages, Balinese language has several dialects. According to Sandhyadwaya (2013), Balinese dialect is distinguished into two big groups namely Bali Aga and Bali Dataran. Bali Aga Language is used by the people who live in mountain range such as, Tenganan, Seraya, Songan, Bantiran, Pedawa, Cempaga, Sembiran and etc. Meanwhile Bali Dataran Language is used by the people who live in coastal area such as, Karangasem, Klungkung, Gianyar, Bangli, Tabanan, Buleleng, 
Badung and Negara. As an island which has strong culture and language, Balinese language is built from different dialects. Batusesa dialect is one of the examples of dialect diversity in Bali, in which all of villagers speak Batusesa. Considering of the importance of Batusesa dialect, which is very unique in tem of pronunciation, accent, and vocabulary, the existence of Batusesa dialect should be maintained. It can be used to enrich the Indonesian culture which has thousands of languages and dialects.

In this study, the researcher tries to analyze the derivational and inflectional prefixes and suffixes and also the grammatical function of the derivational and inflectional morpheme in Batusesa Dialect of Balinese. For the example: ubad 'medicine'is attached to prefix \{me-\} becomes mubad 'on medical treatment'. The prefix \{me-\} in mubad change the word class of ubad from noun becomes verb, in this case the verb mubad undergoes derivational process, which is affix forming verb. So, the way how word is formed in Batusesa dialect of Balinese can clearly be understood.

Some researchers had done some researches about Bahasa Bali, some of them are "Morphology Bahasa Bali " by Wayan Jendra (1977). Other researches had done by Anggayana entitled Affixation of Bugbug Dialect: A Descriptive Study (2014), An Analysis of Derivational and Inflectional Morphemes in Nusa Penida Dialect (2014) by I Kadek Mantra, . I Made Lintana Riasa in 2015 conduct the study about Derivational and Inflectional Process in Lemukih dialect.

To give contributions in morphology of Bahasa Bali especially for its derivational and inflectional processes, the researcher wants to conduct research in Batusesa dialect of Balinese as part of Bahasa Bali which is spoken by the villagers in Batusesa.

\section{METHOD}

This research belongs to descriptive qualitative study with interview technique by choosing the appropriate informants. The subjects of this study are the people especially the villagers of Batusesa Village who speak and use Batusesa dialect as a mean of their communication. The objects of the study are the prefixes and suffixes which exist in Batusesa dialect. Derivational and inflectional process was selected because they have some unique factor to be researched, those are pronunciation, dialect, and intonation.

This study involves the representative of the native speakers of Batusesa Village as the informants. The informants of this research were the villagers of Batusesa Village who give clear and accurate information related to the research. In this study the researcher use three informants, they are main informant and secondary informant. In obtaining the data the researcher used three techniques of the data collection, namely participatory observation, recording technique and interview technique. Participatory observation is a kind of technique which is used by the researcher to observe the language that is used by the people in Batusesa Village and the researcher directly involved in the observation, such as involved in traditional ceremony. Recording technique is a technique which is used by the researcher to record the language used spontaneously. And interview technique is a technique in which the researcher listen to the spontaneous use of language thoroughly and while noting, the researcher also note to a relevant data according to the goal of doing research.

In obtaining the data, the researcher used two instruments: tape recorder and word list (the list of words contains prefixes and suffixes which were taken from Nothover and Swadesh word list and also some words which contains prefixes and suffixes in 
Bahasa Indonesia). The tape recorder is used to record the use of spoken language spontaneously.

The identification of data was analyzed by Interactive Data Analysis Model. According to Miles and Huberman (1994), there are three processes in analyzing the data. Those are : 1) Data Reduction refers to the process of selecting, focusing, simplifying, abstracting, and transforming the data that appear in written up field notes or transcript. 2) Data display goes a step beyond data reduction to provide "an organized, compressed assembly of information that permits conclusion drawing". A display can be an extended piece of text or diagram, chart or matrix that provides a new way of arranging and thinking about the more textually embedded data. 3) Conclusion drawing and verification involves stepping back to consider what the analyze data mean and to assess their implication for the questions at hand. In this study, firs process of the analysis. The researcher will identify the word and the affixes attached of Batusesa dialect spoken by the informants and the villagers of Batuusesa Village, and the next process is to identify the morpheme in the word whether those are derivational or inflectional morpheme. The last process is grouping the morpheme, giving examples of sentences and then drawing about the result.

\section{FINDING AND DISCUSSION}

\section{Derivational and Inflectional Prefixes and Suffixes in Batusesa Dialect}

There are three kinds of derivational prefixes in Batusesa dialect. Those are $\{\mathrm{n}-\}$, $\{\mathrm{me}-\}$ and $\{$ pe- $\}$.

a. The prefix $\{n-\}$ in Batusesa dialect has three variations when a basic form is attached to it. The first is the original form of prefix $\{n-\}$.

$$
\{\mathrm{n}-\}+\text { tepung }(\mathrm{N}) \longrightarrow \text { nepung } \quad\left[\begin{array}{lll}
\mathrm{n} & \mathrm{p} & \mathrm{y}
\end{array}\right](\mathrm{V})
$$

Cang meli tepung di peken (I buy powder in the market)

Cang nepung baas anggo ngae jaja (I crush the rice to make some cakes)

Based on the data above, it shows that there is a derivational process occur, where it change the class as well as the meaning of the base word. For the example the word \{tepung\} 'powder' becomes \{nepung\} 'crush the rice'. It shows that the word class is changing from noun to verb.

The second is prefix $\{\mathrm{n}-\}$ becomes $\{\tilde{\mathrm{n}}-\}$, Prefix $\{\tilde{\mathrm{n}}-\}$ is used before a base which has consonant with initial /c/, /s/.

I meme ngae sampat lidi (My mother makes a broom)

I meme nyampat di kamar tamu (my mother sweep in the living room)

Based on the data above, it can be seen that when prefix $\{n-\}$ is attached to the nominal bases which has initial consonant $/ \mathrm{c} /$ and $/ \mathrm{s} /$, it change the word class and also the meaning of the word. Fr the example the word \{sampat\} which mean as 'broom' attached to the prefix $\{\mathrm{n}\}$ become \{nyampat\} which mean 'sweep'. This process changes the class of the word from noun into verb.

The third is prefix $\{n-\}$ is pronounced $\{n-\}$, it occurs when prefix $\{n\}$ is attached to the bases which are preceded by initial vowel.

I bapa ngabe arit ke uma my father brings a sickle to the rise field

I bapa ngarit di uma (my father cut the grass in the rice field)

The data above show that when the prefix $\{n-\}$ is attached to the nominal base, it undergoes a derivational process. It can be seen in the example above the word \{arit\} which has meaning as 'sickle' attached to prefix $\{n-\}$ it become \{ngarit\} which has meaning as 'cut the grass'. The class of the word is changing from noun into verb. 
b. Prefix $\{m e-\}$

di peken liu ada dagang (In themarket there are a lot of merchants)

di peken liu anake medagang buah-buahan (In the market there are a lot of people who sell fruit)

The data above show that the process of attaching prefix $\{$ me- $\}$ to the nominal base undergoes a derivational process. In which it change the class of the word as well as the meaning of the word. For the example, the word \{dagang\} which means 'merchant' attached to prefix $\{$ me- $\}$ becomes \{medagang\} which mean "to sell'. The word class changes from the noun into the verb as well as the meaning of the word.

c. Prefix $\{\mathrm{pe}-\}$

takon malu ngajak I bapa (ask to our dad first)

nak cerik ento tusing taen nyautin petakon (that kid never answer my question)

The data above show that there is derivational process occur when prefix $\{\mathrm{pe}-\}$ is attached to the verbal base. It changes the meaning of the word and also the class of the word. It can be found in word \{takon $\}$ means ask attached to the prefix \{pe-\} it becomes petakon which mean as questions.

\section{Suffixes in Batusesa dialect of Balinese which Belong to Derivational Morpheme}

Suffix $\{$-ang

ngemula biu petang puun, abesik tusing ada idup (planting four bananas, none is alive)

Luh, idup sep lampune! (Luh, please turn on the lamp)

It can be seen that there is a derivational process occur when the suffix $\{-a n g\}$ is attached to the adjectival and nominal base. In can be found in the word \{idup\} which means 'alive' as adjective, when it is attached to the suffix \{-ang\} it become \{idupang\} which mean 'turn on' as verb.

\section{Prefixes in Batusesa Dialect which Belong to Inflectional Morpheme}

\section{a. Prefix $\{n-\}$}

1. tegarang tulis di papan tulis! (Please write on the black board!) tiyang melajah nulis puisi (I learn to write poetry)

2. bli, tulung jemak jep pajenge! (Bli, please take the umbrella!) tiyang nyemak biu duang igas (I take two bunch of bananas)

The data above show that the process of adding prefix $\{n-\}$ to the verbal base does not change the word class as well as the meaning of the word. It can be classified as inflectional morpheme in Batusesa dialect.

b. Prefix $\{a-\}$

In Batusesa dialect, the process of attaching prefix $\{\mathrm{a}-\}$ to the nominal base has meaning of number. It undergoes inflectional process, in which the meaning and the class of the word still the same. For the example:

I Baba ngemula nyuh limang puun (My father plants five coconut trees)

I Bapa ngaba biu apuun (My father bring a banana tree)

c. Prefix $\{$ me- $\}$

Gandong nyen adine tuunan Tu! (Carry on the back your sister go down Tu!)

Luh Ayu megandong ajake beline. (Luh Ayu is carried on the back by her brother)

The data above show that the processes of attaching prefix $\{\mathrm{me}-\}$ to the verbal base undergo inflectional process. In which after the addition of prefix $\{\mathrm{me}-\}$ to the verbal base it does not make any changing in term of meaning as well as the class of the word. 


\section{Suffixes in Batusesa dialect which Belong to Inflectional Morpheme}

There are four kinds of inflectional suffixes found in Batusesa dialect. They are \{$\mathrm{n}\},\{-\mathrm{in}\},\{-\mathrm{an}\}$, and $\{-\}$.

a. Suffix $\{-n\}$

In Batusesa dialect undergoes derivational process. In Batusesa dialect, when suffix \{$\mathrm{n}\}$ is added to the nominal base. It does not change the word class and the meaning of the word. For the example:

lan jajane gae malunan (Let's make the cake first)

jaja sube gaene ibi (the cake has made yesterday)

Refering to the example above, it can be seen that the attachment of suffix $\{-n\}$ incurs inflectional process. It doesn't change the meaning nor the class of the word. So that it can be classified as inflectional morpheme.

b. Suffix $\{$-in $\}$

In Batusesa dialect, when suffix $\{$-in $\}$ is attached to the verbal bases, it undergoes inflectional process. For the example:

nang sambat adane! (Mention your name please!)

sambatin jep men Putu orain nyemak bajune (Please tell men Putu to take her shirt)

The example above show that when suffix $\{$-in $\}$ is added to the verbal bases, it does not change the word class and the meaning itself. The word class is still the same, namely verb. So that, the suffix $\{-$ in $\}$ can be classified into inflectional morpheme as it incurs inflectional process.

c. Suffix $\{$-an

In Batusesa dialect is found suffix $\{-a n\}$, in which when it is attached to the adjectival bases, it doesn't change the rule of the base in term of the word class nor the meaning of the word. For the example:

umah tiyange cenik sajan (my house is so small)

kamar tiyange cenikan tekan kamar belin tiyange (My room is smaller than my brother's)

Based on the data above, it can be seen that the process of adding suffix $\{-a n\}$ to the nominal base does not undergo any changing to the word whether in term of the class word or the meaning of the word. The process of attaching suffix $\{-\mathrm{an}\}$ to the adjectival base indicate comparative degree. Furthermore it can be classified as inflectional morpheme.

d. Suffix $\{-\}$

Suffix $\{-\}$ in Batusesa dialect is used when a base morpheme which is attached is ending by final consonant. When the suffix $\{-\partial\}$ is attached to the verbal bases, it does not change the word class or the meaning of the word. For examples:

Tugel timune bang adine bedik (Cut the cucumber and give a bit to your sister)

Timune tugele teken I meme (The cucumber was cut by mom)

The data above show that when a verbal base is attached to suffix $\{-\partial\}$, the word class of the base does not change. Therefore, the attachment of suffix $\{-\partial\}$ to the verbal bases performs inflectional process. Besides, suffix $\{-\partial\}$ can be classified into inflectional morphemes.

\section{The Grammatical Functions of the Prefixes and Suffixes in Batusesa Dialect of Balinese}

Based on the prefixes and suffixes had been analyzed, there were some grammatical functions appear when the prefixes and suffixes were attached to a root or 
base. there are four functions of derivational prefixes and suffixes after they attached to root. The functions are Nominalizer, Adjectivalizer, Verbalizer, and Adverbializer.

a. The function of prefix $\{n-\}$

Prefix $\{n-\}$ when it is attached to the base or root, it undergoes derivational process, in which it change the word class into the verb and makes an active form. In this study, the function of prefix $\{\mathrm{n}-\}$ in Batusesa Dialect of Balinese is affix forming verbal (verbalizer) For the example:

I meme ngae sampat lidi (My mother makes a broom)

I meme nyampat di kamar tamu (My mother sweep in the living room)

b. The Function of Prefix $\{$ me- $\}$

Prefix \{me- $\}$ in Batusesa dialect can be attached to many kinds of base words. When prefix $\{m e-\}$ is attached to the base form, it change the class of the word. It changes the word into verb, and also forms active and passive form. For the example:

Gandong nyen adine tuunan Tu! (Carry on the back your sister go down Tu!)

Luh Ayu megandong ajake beline (Luh Ayu is carried on the back by her brother)

c. The function of prefix $\{p e-\}$

Prefix \{pe- $\}$ in Batusesa dialect of Balinese undergoes derivational process. When it is attached to the base form, it changes the class of the base form. In this study, the function of prefix $\{\mathrm{pe}-\}$ in Batusesa dialect of Balinese is an affix forming nominal (nominalizer).

takon malu ngajak I bapa (ask to our dad first)

nak cerik ento tusing taen nyautin petakon ( that kid never answer my question)

Based on the data above, it can be seen that the function of prefix $\{p e-\}$ in Batusesa dialect is an affix forming nominal (nominalizer). It undergoes derivational process because the class of the base word changes from verb into noun.

d. The Function of prefix $\{a-\}$

Prefix $\{a-\}$ in Batusesa dialect undergo inflectional process, it does not change the class of the word after the addition of prefix $\{a-\}$. Nor, the addition of prefix $\{a-\}$ in to the base form change the meaning and the grammatical function of the word. In this study, the function of prefix $\{a-\}$ in Batusesa dialect of Balinese is affix forming numeral. For the example:

Petang tiban sube ia nganten (he has been married for four years)

Sube atiban tusing taen matepuk ngajk kerenane (It has been one year he doesn't meet his wife)

From the explanation above, prefix $\{\mathrm{a}-\}$ as affixes forming numeral is because it change the meaning and grammatical function as a numbering word. Prefix $\{a-\}$ is always explain number one (see the example one year).

e. The Function of Suffix $\{$-ang

Suffix $\{$-ang $\}$ in Batusesa dialect of Balinese undergoes derivational process. It changes the meaning, grammatical function and also the class of the word. In this study, the function of suffix $\{-$ ang $\}$ is affix forming verb (verbalizer) or imperative sentence. For the example:

ngemula biu petang puun, abesik tusing ada idup (Planting four bananas, none is alive) Luh, idup sep lampune! (Luh, please turn on the lamp)

Based on the data above, suffix \{-ang\} change the class of the word as well as the meaning and the grammatical function of the word. The function of suffix $\{$-ang $\}$ in Batusesa dialect of Balinese is affix forming verbal.

f. The Function of Suffix $\{-n\}$ 
Suufix $\{-n\}$ in Batusesa dialect of Balinese undergo inflectional process. When it is attached to the base form, it does not change the class of the word but it changes the meaning and the grammatical function of the word. In this study, the function of suffix $\{-n\}$ in Batusesa dialect of Balinese is passivizer. It makes the base form become a passive form. For the example:

lan jajane gae malunan (let's make the cake first)

jaja sube gaene ibi (the cake has made yesterday)

Based on the data above, suffix $\{-n\}$ in Batusesa dialect belongs to inflectional morpheme. It does not change the class of the word, nor it changes the meaning and the grammatical function of the word. And the function of the suffix $\{-n\}$ in Batusesa dialect of Balinese is passivizer.

g. The Function of suffix $\{-$ in $\}$

The suffix $\{-\mathrm{in}\}$ is attached to the root or base, it makes verb imperative form. In this study the function of suffix $\{-\mathrm{n}\}$ in Batusesa dialect of Balinese are affix forming verbal (imperative). Suffix $\{-\mathrm{in}\}$ as affix forming verbal (imperative) is when suffix makes verbal (imperative) form. For example:

jang remote duur TVne (put the remote on the TV)

jangin jukute uyah (pour some salt to the soup)

Based on the data above, it can be seen that the function of suffix $\{$-in $\}$ in Batusesa dialect of Baliense is affix forming verbal (imperative).

h. The Function of Suffix $\{-a n\}$

Suffix $\{-a n\}$ when it is attached to the root or base word, it undergoes inflectional process, it does not change the class of the word, however it change the grammatical meaning of the word. In this study, the function of suffix $\{$-in $\}$ in Batusesa dialect of Balinese is affix forming adjective (comparative). For the example:

Putu Ayu bajang jegeg uli Desa Tengah (Putu Ayu is a beautiful girl from Tengah Village)

Putu Ayu jegegan teken mbokne(Putu Ayu is more beautiful than her sister)

From the explanation above, Suffix $\{-\mathrm{an}\}$ in Batusesa dialect of Balinese does not change the word class of base or root, however it changes the grammatical meaning of word. If suffix $\{-a n\}$ is attached to verb form, it will makes imperative form. However, if it attached to adjective form, it forms an adjective comparative form.

i. The Function of Suffix $\{-\}$

Suffix $\{-\}$ when it is attached to the root or base word does not change the class of the word. However, it changes the meaning and the grammatical function of the word. In this study, the function of suffix $\{-\}$ in Batusesa dialect of Balinese is passivizer. It makes the base form become a passive form. For the example:

Tugel timune bang adine bedik (cut the cucumber and give a bit to your sister)

Timune tugele teken I meme (the cucumber was cut by mom)

Based on the data above, suffix $\{-n\}$ in Batusesa dialect belongs to inflectional morpheme. It does not change the class of the word, nor it change the meaning and the grammatical function of the word. And the function of the suffix $\{-n\}$ in Batusesa dialect of Balinese is passivizer.

Based on the finding above, in Batusesa dialect there are four kinds of prefixes namely $\{\mathrm{n}-\},\{\mathrm{me}-\},\{\mathrm{pe}-\}$, and $\{\mathrm{a}\}$ and five kinds of suffixes namely $\{-\mathrm{ang}\},\{-\mathrm{ne}\},\{-$ in $\},\{-a n\}$ and $\{-\partial\}$. Those prefixes and suffixes are categorized into derivational and inflectional prefixes and suffixes. Derivational prefixes involves $\{n-\},\{m e-\},\{p e-\}$, 
inflectional prefixes involves $\{n-\},\{$ me- $\}$ and $\{a\}$. Meanwhile derivational suffix is $\{-$ ang $\}$ and inflectional suffix involves $\{-$-ne $\},\{-$ in $\},\{-$ an $\}$ and $\{-\partial\}$.

Prefix $\{n-\}$ in Batusesa dialect has three variations when a base form attached to it. The original of prefix $\{n-\}$ and there are two allomorph of prefix $\{n-\}$ appear in the attachment of prefix $\{n-\}$ to the bases which incur derivational process and also inflectional process, those allomorph namely $\{\tilde{\mathrm{n}}-\}$ and $\{\mathrm{n}-\}$. In Batusesa dialect found prefix $\{$ me- $\}$. Prefix $\{$ me- $\}$ undergoes two process both derivational and inflectional when it is attached to the bases of the word. Moreover, prefix \{pe- $\}$ also found in Batusesa Dialect it undergoes derivational process when it is attached to the bases of the words. In Batusesa dialect also found prefix $\{a-\}$,the process of attaching prefix $\{a-\}$ to the nominal base has meaning of number. It undergoes inflectional process, in which the meaning and the class of the word still the same. It doesn't undergo any changing to the meaning and also the class of the word.

There are five kinds of suffixes found in Batusesa Dialect, namely $\{$-ang $\},\{$-ne $\}$, $\{-$ in $\},\{-a n\}$ and $\{-\partial\}$. In Batusesa dialect there is only one derivational suffix. It is derivational suffixes $\{$-ang $\}$. When the suffix $\{$-ang $\}$ is attached to the bases, it doesn't change the base of the words. When suffix $\{$-ang $\}$ is attached to the adjectival and nominal base, it change the meaning and also the class of the word. It means that the process of attaching suffix -ang\} to the adjectival base undergoes derivational process. Meanwhile, in Batusesa Dialect there are four kinds of inflectional suffix, In Batusesa dialect, when suffix $\{-n\}$ is added to the nominal base. It does not change the word class and the meaning of the word, it also occur in suffix $\{-$ in $\},\{-$ an $\}$ and $\{-\partial\}$, when it is attached to the bases of the word it does not undergoes any changing in term of class and the meaning of the word.

Based on the data found, the prefixes and suffixes which belong to derivational and inflectional which exist in Batusesa dialect have some similarities and differences if it is compared to the other dialect in Bali. Comparing with Pelaga Dialect which was conducted by Wiwaka (2014), Bugbug Dialect which was conducted by Anggayana (2014) and Nusa Penida Dialect which was conducted by Mantra (2014). All of those dialects have similarities in term of prefixes $\{n-\}$ and $\{a-\}$ and suffix $\{-a n g\}$. Prefixes $\{\mathrm{n}-\}$ and $\{\mathrm{a}-\}$ and suffix $\{-\mathrm{ang}\}$ exist in those dialects. Meanwhile, comparing with Bugbug Dialect which also located in Karangasem Regency, both of Batusesa and Bugbug Dialect have prefix $\{$ me- $\}$ and suffix $\{-n e\},\{-$ in $\}$ and $\{-\}$. Meanwhile prefix $\{\mathrm{pe}-\}$ also does not exist in both of Bugbug and Nusa Penida Dialect.

The grammatical function of prefixes and suffixes in Batusesa dialect of Balinese, namely affix forming verbal, affix forming nominal, affix forming numeral, affix forming adjective, and affix forming adverb, activezer and passivizer.

\section{CONCLUSION}

Based on the statement of the problem, finding and discussion stated previously, it can be concluded that:

a. Batusesa dialect has three kinds of derivational prefixes, those are $\{\mathrm{n}-\},\{\mathrm{me}-\}$, and $\{$ pe- $\}$. Three kinds inflectional prefixes: $\{n-\},\{m e-\}$, and $\{a-\}$. One kind of derivational suffixes namely $\{$-ang $\}$ and four kinds inflectional suffixes: $\{-n\},\{-i n\}$, $\{-$ an $\}$, and $\{-\}$.

b. Three kinds of prefixes belong to derivational morpheme namely prefixes $\{n-\}$, \{me\} , and $\{\mathrm{pe}-\}$. Those three prefixes undergo derivational process when it is attached to nominal bases. Moreover there is only one kind of suffixes which belongs to 
derivational morpheme, namely suffix $\{$-ang $\}$, in which when suffix $\{$-ang $\}$ is attached to the adjectival bases it undergo derivational process.

c. There are three kinds of inflectional prefixes which belong to inflectional morpheme, namely prefixes $\{n-\},\{m e-\}$, and $\{a-\}$. 1) Prefix $\{n-\}$ undergoes inflectional process when it is attached to the verbal base; 2) prefix \{me- $\}$ undergoes inflectional process when it is attached to verbal base; 3 ) prefix $\{a-\}$ undergoes inflectional process when nominal bases are attached to it. There are four kinds of inflectional suffixes which belong to inflectional morpheme, namely 1) suffix $\{-n\}$ undergoes inflectional process when it is attached to the verbal bases; 2) suffix $\{$-in $\}$, inflectional process occur when suffix $\{-$ in $\}$ is attached to the verbal bases; 3) suffix $\{$-an\} incurs inflectional process when it is attached to the adjectival bases; 4) suffix $\{-\}$ undergoes inflectional process when verbal bases are attached to it.

d. There were some grammatical functions of prefixes and suffixes in Batusesa dialect of Balinese, namely affix forming verbal, affix forming nominal, affix forming numeral, affix forming adjective, and affix forming adverb, activezer and passivizer. 1) The function of prefix $\{\mathrm{n}-\}$ is verbalizer (affix forming verbal); 2 ) the functions of prefix $\{$ me- $\}$ is affix forming erbal, activizer and passivizer; 3 ) the function of prefix $\{$ pe- $\}$ in Batusesa dialect of Balinese is an affix forming nominal (nominalizer); 4) the function of prefix $\{a-\}$ in Batusesa dialect of Balinese is affix forming numeral; 5) the function of suffix $\{-\mathrm{ang}\}$ is affix forming verb (verbalizer) or imperative sentence; 6 ) the function of suffix $\{-n\}$ in Batusesa dialect of Balinese is passivizer. It makes the base form become a passive form; 7) the function of suffix $\{-n\}$ in Batusesa dialect of Balinese are affix forming verbal (imperative); 8) the function of suffix $\{-$ in $\}$ in Batusesa dialect of Balinese is affix forming adjective (comparative); 9) the function of suffix $\{-\}$ in Batusesa dialect of Balinese is passivizer.

\section{REFERENCES}

Abdussalam \& Mahmud, S. (2014). Gayo Language Is Old Malay (A Dialectology Study: The Language Change). Englisia, 1(2), 191-215. Retrieved from http://jurnal.ar-raniry.ac.id/index.php/englisia/article/download/28/23

Affifah, R. (2012). Word Formation Process in Slank Word Used by Transsexual . Retrieved from: https://core.ac.uk/download/pdf/11733666.pdf

Aronoff, M. \& Fudeman, K. (2011). What is Morphology? Retrived from http://www.ucd.ie/artspgs/introling/Aronoffmorphology.pdf

Brett, D. (2013).Derivational and inflectional morphemes. Retrieved from http://davidbrett.uniss.it/morphology/derivInflect.html

Budasi, I. G. (2007). Kekerabatan bahasa-bahasa di sumba (suatu kajian linguistik hipotesis, komperatif (disertasi). Yogyakarta: Fakultas Pascasarana Universitas Gajah Mada.

Carstairs, A. \& McCarthy, (2002). An Introduction of Morphology. Retrieved from http://logic.sysu.edu.cn/ebookfull/UploadFiles_7160/200905/200905061709557 9.pdf

Chaer, A. (2003). Linguistik Umum. Jakarta: PT Rineka Cipta.

Chaer, A.2015. Morpologi bahasa Indonesia (pendekatan proses). Jakarta: Rineka Cipta.

Enrilefariz, (2015). What is the Morphology? (EN/INA). Retrived from https://enrilefariz.wordpress.com/2015/12/27/what-is-the-morphology/ 
Fazaelly, S. (2013). A Study on the Affixation Process of Sadeq Hedayat's and Jalal Ale Ahmad's Works. Retrieved http://ijee.org/yahoo_site_admin/assets/docs/8.89113418.pdf

Ghozali, A. (2014). morphological process. Retrieved from http://www.slideshare.net/ghozaliaffan/morphological-process.

Haspelmath, M. \& Sims, A D. (2010). Understanding Morphology. Retrieved from http://202.121.96.130/download/20140401232730644.pdf

Hosseinzadeh at all, 2014. The Assimilation of Consonants in Eghlid, an Iranian Dialect. Retrieved from http://www.eajournals.org/wp-content/uploads/TheAssimilation-of-Consonants-in-Eghlid-an-Iranian-Dialect1.pdf

http://www.kul.pl/files/30/UW/06Morphology-class-handout.pdf morphology 66

Ingo, P. (2002). Word-formation in English. Retrived from http://www2.unisiegen.de/ engspra/plag-in-press.pdf

Jaten, I ketut. ( 2010). Pura Pelawangn Agung Batusesa. Denpasar. Paramita

Jendra, at all. (1977). Morpologi Bahasa Bali. Denpasar:Univesitas Udayana

Kridalaksana, H. (1996). Pembentukan Kata Dalam Bahasa Indonesia, Edisi kedua. Jakarta: Gramedia Pustaka Utama.

Kridalaksana,H. (2007). Pembentukan Kata DalamBahasa. Jakarta: GramediaPustakaUtama.

Mahadwipa, K. A. (2012). A Morphophonemic Analysis of Balinese Affixes of Madenan Dialect. Singaraja: Universitas Pendidikan Ganesha.

Mantra, I. K. (2014). An Analysis of Derivational and Inflectional Morpheme in Nusa Penida Dialect. Singaraja: Universitas Pendidikan Ganesha.

Miles, M. W. \& Huberman, A. M. Qualitative Data Analysis (2nd ed.) London: Sage Publications.

Moradi, Rasool. (2014). Derivation and Inflection in Laki. International Journal of Management and Humanity Sciences, 3 (12), 3832-3836. Retieved from http://ijmhsjournal.com/wp-content/uploads/2015/01/3832-38361.pdf

Nordquist, R. (2015). derivational morpheme (words and word parts). Retrieved fromhttp://grammar.about.com/od/d/g/Derivational-Morpheme.html

Oiry, (2009). morphology. retrived from http://people.umass.edu/moiry/morphology.pdf

Parera, J. D. (2007). Morfologi. Jakarta: PT Gramedia Pustaka Utama.

Parker, Mattew D. 2005. A Comparative Study Between Mean Length of Utterances in Morphemes. Retrieved from http ://www.researchgate.net

Quinion, M (2009). Affixes: the building blocks of English. Retrived from http://www.affixes.org/typesofaffix.html

Riasa, I M. L. (2015).Affixation in Lemukih Dialect of Balinese: a Descriptive study of Derivitional and InfluctionalProcess.Singaraja: Universitas Pendidikan Ganesha.

Samarin, W.J. (1967). Field Linguistic: A Guide to Linguistic Filed Work. United State: Hold Rinehartan Wiston.

sandhyadwaya, (2013). Dialect Bahasa Bali. Retrieved from https://sandhyadwaya.wordpress.com/2013/08/21/dialek-basa-bali/

Sari, N. (1988). An Introduction to Linguistics. Jakarta: Proyek Pengembangan Lembaga Pendidikan Tenaga Kependidikan (P2LPTK). 
Umera-Okeke, N. (2007). Exploring Affixation in English. Retrieved from file://C:/Users/acer/Downloads/41010-19496-1-PB.pdf.

Vikram, Shweta. (2013). Morphology: Indian Languages and European Languages. International 